УдК 550.4.01

\title{
REGULARITIES OF HYDROCARBON DEPOSITS PLACEMENT IN THE CRYSTALLINE BASEMENT AND SEDIMENTARY COVER WITHIN YULIYIVSKO-SKYVORTSIVSKY POLYGON FROM THE STADPOINT OF TECHNOLOGY STAGR
}

\author{
I.D. Bagriy1, D.M. Bozhezha' ${ }^{2}$, Yu.K. Gordieieva ${ }^{3}$, K.M. Starodubets ${ }^{4}$ \\ (Recommended by academician of NAS of Ukraine P.F. Gozhik)
}

\author{
${ }^{1}$ Institute of Geological Sciences of NAS of Ukraine, Kyiv, Ukraine, E-mail: bagrid@ukr.net \\ Doctor of geological sciences, senior researcher. \\ ${ }^{2}$ Institute of Applied Problems of Ecology, Geophysics and Geochemistry, Kyiv, Ukraine, \\ E-mail: bozhezha@gmail.com \\ Senior research worker. \\ ${ }^{3}$ Taras Shevchenko National University of Kyiv, Institute of Geology, Kyiv, Ukraine, E-mail: u_gordeeva@mail.ru \\ PhD student. \\ ${ }^{4}$ Institute of Geological Sciences of NAS of Ukraine, Kyiv, Ukraine, E-mail: starodubets.kirill@ukr.net \\ Researcher associate.
}

The materials of structural-thermal-atmo-geochemical research (STAGR) carried out within Yuliyivsko-Skvortsivsky polygon are analyzed. The relationship between geological structure, structural-tectonic position of YuliyivskoSkvortsivskiy polygon, patterns of distribution of hydrocarbons deposits within it and the nature of the fields produced by them are characterized. The most promising and relatively promising areas in terms of oil and gas bearing capacity are selected.

Key words: crystalline basement, Yuliyivsko-Skvortsivsky polygon, structural-thermal-atmo-geochemical researches (STAGR), oil and gas bearing capacity.

\section{ЗАКОНОМІРНОСТІ РОЗМІЩЕННЯ РОАОВИЩ ВУГАЕВОАНІВ У КРИСТААІЧНОМУ ФУНААМЕНТІ ТА ОСААОВОМУ ЧОХАІ У МЕЖАХ ЮАІЇВСЬКО-СКВОРЦІВСЬКОГО ПОАІГОНУ З ПОЗИЦІЙ ТЕХНОАОГІЇ СТАГА}

\author{
І.Д. Багрій', Д.М. Божежа², Ю.К. Гордєєва ${ }^{3}$, К.М. Стародубець ${ }^{4}$ \\ (Рекомендовано акад. НАН України П.Ф. Гожиком)
}

\author{
${ }^{1}$ Інститут геологічних наук НАН Украӥни, Київ, Украӥна, E-mail: bagrid@ukr.net \\ Доктор геологічних наук, стариий науковий співробітник. \\ ${ }^{2}$ Iнститут прикладних проблем екології, геофізики та геохімії, Київ, Україна, E-mail: bozhezha@gmail.com \\ Старший науковий співробітник. \\ ${ }^{3}$ Київський національний університет імені Тараса Шевченка, ННІ “Інститут геології, Київ, Украӥна, \\ E-mail: u_gordeeva@mail.ru \\ Аспірант. \\ ${ }^{4}$ Інститут геологічних наук НАН України, Київ, Україна, E-mail: starodubets.kirill@ukr.net \\ Молодиий науковий співробітник
}

Проаналізовано матеріали структурно-термо-атмогеохімічних досліджень (СТАГД), виконаних у межах Юліївсько-Скворцівського полігону. Охарактеризовано взаємозв' язок геологічної будови, структурно-тектонічної позиції Юліївсько-Скворцівського полігону, закономірностей розміщення покладів вуглеводнів у його межах та характеру полів, що продукуються ними. Виділено найбільш перспективні та умовно перспективні з точки зору нафтогазоносності ділянки.

Ключові слова: кристалічний фундамент, нафтогазоносність, Юліївсько-Скворцівський полігон, структурнотермо-атмогеохімічні дослідження (СТАГД).

(C) I.D. Bagriy, D.M. Bozhezha, Yu.K. Gordieieva, K.M. Starodubets, 2017 


\title{
ЗАКОНОМЕРНОСТИ РАЗМЕЩЕНИЯ МЕСТОРОЖАЕНИЙ УГАЕВОАОРОАОВ В КРИСТАМАИЧЕСКОМ ФУНААМЕНТЕ И ОСААОЧНОМ ЧЕХАЕ В ПРЕАЕААХ ЮАИЕВСКО-СКВОРЦОВСКОГО ПОАИГОНА С ТОЧКИ ЗРЕНИЯ ТЕХНОАОГИИ СТАГИ
}

\author{
И.Д. Багрий ${ }^{1}$, Д.Н. Божежа ${ }^{2}$, Ю.К. Гордеева ${ }^{3}$, К.Н. Стародубец ${ }^{4}$ \\ (Рекомендовано акад. НАН Украинь П.Ф. Гожиком)
}

\author{
${ }^{1}$ Институт геологических наук НАН Украины, Киев, Украина, E-mail: bagrid@ukr.net \\ Доктор геологических наук, старший научный сотрудник. \\ ${ }_{2}^{2}$ Институт прикладных проблем экологии, геофизики и геохимии, Киев, Украина, \\ E-mail: bozhezha@gmail.com \\ Стариий научный сотрудник. \\ ${ }^{3}$ Киевский национальный университет имени Тараса Шевченко, УНИ “Институт геологии”, Киев, \\ Украина, E-mail: u_gordeeva@mail.ru \\ Аспирант. \\ ${ }^{4}$ Институт геологических наук НАН Украины, Киев, Украина, \\ E-mail: starodubets.kirill@ukr.net \\ Младиий научный сотрудник.
}

Проанализированы материалы структурно-термо-атмогеохимических исследований (СТАГИ), проведенных в пределах Юлиевско-Скворцовского полигона. Охарактеризованы взаимосвязь геологического строения, структурно-тектонической позиции Юлиевско-Скворцовского полигона, закономерности размещения залежей углеводородов в его пределах и характера полей, продуцируемых ими. Выделены наиболее перспективные и условно перспективные с точки зрения нефтегазоносности участки.

Ключевые слова: кристаллический фундамент, нефтегазоносность, Юлиевско-Скворцовский полигон, СТАГИ.

Commercial oil deposits in basement rocks are not geological 'accidents' but are oil accumulations which obey all the rules of oil sourcing, migration and entrapment; therefore in areas of not too deep basement, oil deposits within basement rocks should be explored with the same professional skill and zeal as accumulations in the overlying sediments.

Landes (1960), American Association of Petroleum Geologists

\section{INTRODUCTION}

The problem of oil and gas bearing capacity of the crystalline basement takes a special place among the topical problems of petroleum geology and energy in the context of the origin of hydrocarbons. This is related not only with possible grandiosity of its oil and gas resources, but also with particular importance of the researches of this problem to determine general regularities of formation and distribution of hydrocarbons [Лукин, 2004].

Oil and gas bearing of the basement, as well as within sedimentary cover, is established at the beginning of the oil industry. The first industrial influxes were obtained from crystalline rocks of different ages (quartzite, granite, rhyolite) in North America (California, Texas, Oklahoma, Kansas). Their geography has been steadily expanded with attraction of new regions to exploration for oil and gas [Landes, Amoruso, Charlesworth, 1960].

Accumulations of oil and gas in the crystalline basement rocks are open almost every continent and in the world's oceans. Crystalline crust of the Earth is the basement of 60 sedimentary basins with commercial oil and gas deposits in 29 countries of the world. Additionally, there are 496 oil and gas fields in which commercial reserves occur partly or entirely in the crystalline rocks of that basement. 55 of them are classified as giant fields $(>500 \mathrm{Mbbls})$ with 16 non-associated gas, 9 gas-oil and 30 unsaturated oil fields among them. However, despite the opening in the base of industrial fields, including large, targeted search for hydrocarbon deposits in the basement, especially in igneous rocks, are maintained in limited quantities. Even though the fact that according to conservative estimates contained in the crystalline basement $9432109 \mathrm{~m}^{3}$ of natural gas and 32837106 tons of crude oil, $18 \%$ of the total world proven reserves of oil and about 5,4\% of the total world proven reserves of natural gas. This is due to the fact that nature is not clear-capacity basement rocks, not the technique and methods of search of collectors in crystalline rocks in fact of the problem of their opening and development [Kutcherov, Krayushkin, 2010]. 


\section{SURVEY AREA}

In Ukraine there are structures the most promising for the discovering of commercial hydrocarbon deposits in the crystalline basement such as Kovelsky ledge and sides of the Dnieper-Donets basin, especially the northern side. It has a complete set of geological criteria that define it as a primary object for further increasing of proven hydrocarbon reserves. Tectonic factor plays significant role in determining the prospects for the North side and contributes to extensive development of oil- and gas-bearing stratigraphic complexes, monoclinal occurrence of the sedimentary cover, complicated by faults of various directions and types. It also contributes to distribution of various traps for hydrocarbon accumulation, the formation of tectonic boundaries on the ways of hydrocarbon migration, the spatial distribution of hydrocarbon deposits within the local uplifts and structural-tectonic zones, a zonal development of reservoir rocks in both the Precambrian formations and sedimentary cover.

The discoveries of commercial deposits on Yuliyivska, Skvortsivska, Huhrynska, Korobochkinska and other areas allow to prove the potential prospects of crystalline basement rocks (8 deposits in the weathering crusts of the basement and 5 in the decompressed basement rocks below the weathering crust) as objects of oil-and-gas-industrial importance, but insignificant depth of drilling in oil- and gas-bearing crystalline rocks does not enable to make reasonable estimates and predictions.

Structural-thermal-atmo-geochemical researches (STAGR) are conducted by specialists of Institute of Geological Sciences of NAS of Ukraine at the territory of the Dnieper-Donets basin since 1999. During this period, the research of methodological and search directivity have been carried out on 2 landfills, 45 structures and 17 areas, in particular on Yuliyivsko-Skvortsivsky polygon. In the territory of Yuliyivsko-Skvortsivsky polygon on an area of $325 \mathrm{~km}^{2}$, a complex of laboratory and field instrumental thermometric, emanational and geochemical researches on the basis of STAGR methodology was conducted.

\section{SURVEY TARGET}

The investigated object (Yuliyivsko-Skvortsivsky landfill) is situated within the northern edge of the central part of the Dnieper-Donets basin. According to the scheme of oil-gas-geological zoning it is a part of Pivnichnobortova sub-region of Dnieper-Donets oil- and gas-bearing region. Within Yuliyivsko-Skvortsivsky polygon there are common productive complexes of the Precambrian basement, including the weathering crusts and zones of decompressed crystalline rocks, Lower Visean, Upper Visean and Middle Carboniferous rocks. Yuliyivsko-Skvortsivsky landfill consists of Yuliyivska, Skvortsivska, Lyubotynska, Pivnichno-Skvortsivska, Nedilna and Kadnytska area (see Figure 1).

According to of aero-cosmo-geological data, Yuliyivsko-Skvortsivsky landfill has the form of ellipsoidal structure with a long axis that stretches in the north-east. It appears as the uplift in modern relief. The contours of Skvortsivske and Yuliyivske deposits are practically adjacent on the detailed structural maps. The result of the comparison with structural maps for reflecting horizons $\mathrm{Vb}_{2-\mathrm{n}}\left(\mathrm{C}_{1} \mathrm{v}_{2}\right)$ та $\mathrm{Vb}_{3-\mathrm{n}}\left(\mathrm{C}_{1} \mathrm{~V}_{1}\right)$ allows to be identified a series of local structures on the earth's surface as a display of basement units (blocks).

Considering the position and shape of some local ring structures, it can be assumed that they reflect the patterns of crystalline basement which still not discovered by geophysical methods [Багрій, 2013].

The positive anomalies of temperature field records in subsurface layers of the geological environment above the hydrocarbon deposits. Indicators of temperature in subsurface layers of rocks within deposit, especially in its apical part, exceed those indicators beyond the contour of hydrocarbon field. According to the researches, the spatial distribution of the temperatures in subsurface layers of rocks $\mathrm{s}$ is closely connected with the features of the block structure of objects of research: temperature peaks are typical for the least affected tectonic blocks (according to the results of decryption of the seismic survey and satellite survey materials). At the same time, these units are characterized by the lowest gas permeability (according to STAGR).

The maximum quantity of anomalies of radon and thoron must be a sign of an active zone of a new and contemporary geodynamic activity, decompression, fracturing and fluid permeability, respectively.

The integral coefficient of additive sum of the three gases (carbon dioxide, helium and hydrogen) is used as the gas indicator in the subsoil air, based on the assumption that the maximum values will characterize fragments of regional fault zones or lin- 


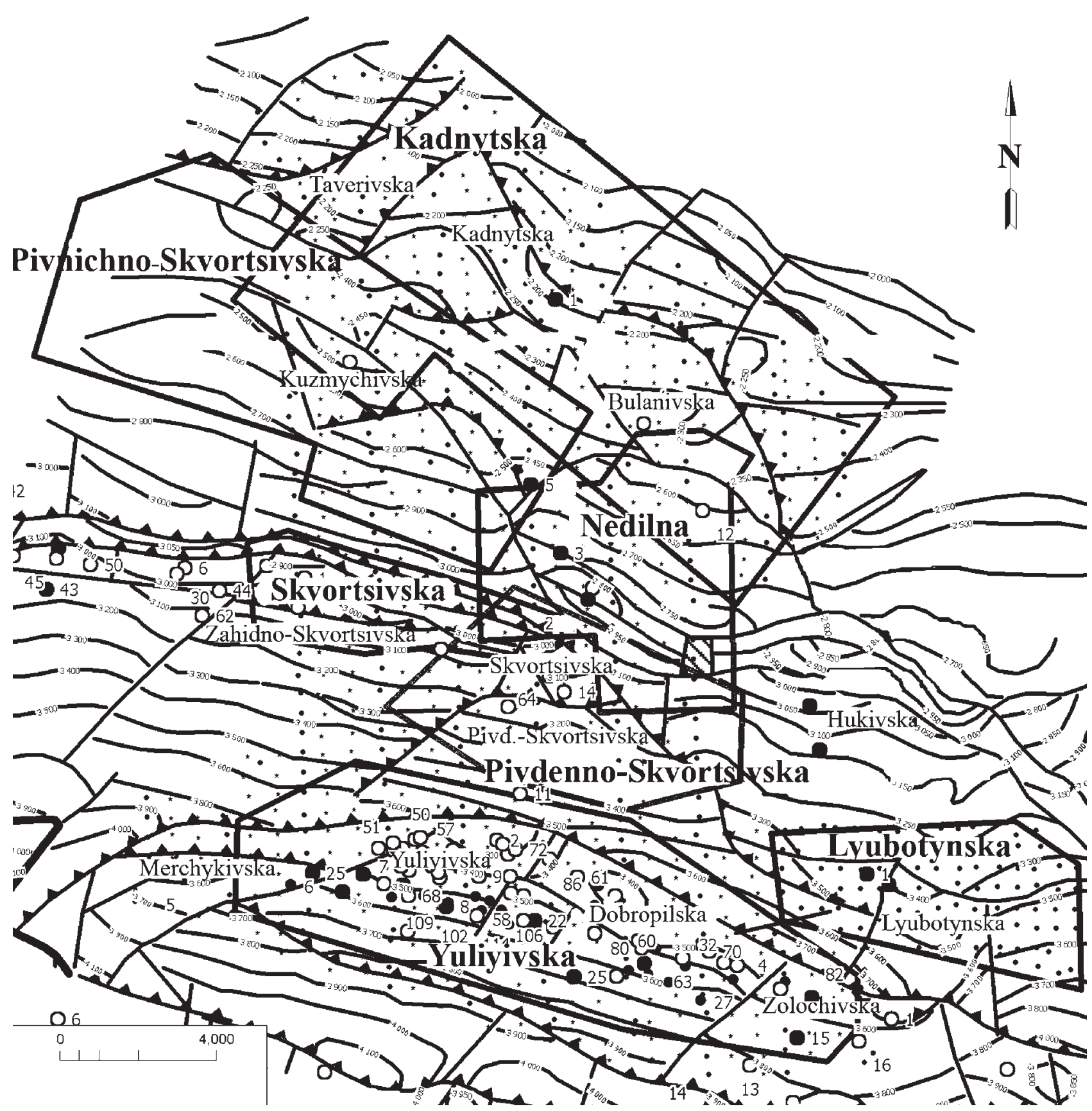

Fig. 1. Location of Yuliyivsko-Skvortsivskiy polygon on the structural-tectonic map

eaments and ring structures. Anomalies of these gases in conjunction with the emanations of radon and thoron may be related to areas of most permeable zones of tectonic activity and may be indicators of their depths.

Hydrocarbon indicators (methane and its homologues) are considered to be indicators of both general perspectivity of predicted object and the degree of tightness of oil and gas fields.

Anomalous field of hydrocarbon gases at presence of the objective data can be used as additional information of so-called "direct" character about the hydrocarbon accumulation in a trap. Revealed peculiarities of their spatial distribution, together with temperature, emanational and gas indicators should be regarded as some information for clarification of prognostic assessment of squares and areas of researches STAGR.

Maps of subsurface discharging of fluid-gas flows fields for the territory of Yuliyivsko-Skvortsivsky polygon (according to temperature of subsoil layer, contents of radon, thoron, helium, carbon dioxide, hydrogen and volatile hydrocarbons in the subsurface layer) illustrate its zoning for areas 
which differ by contemporary geodynamic conditions: neotectonic active and fluid permeable zones tend to tectonic disturbances, or relatively stable tectonic blocks. The last one is the most favorable to formation of hydrocarbon traps, accumulation and preservation of their deposits in consequence of low fluid permeability.

Structural, temperature and atmo-geochemical indicators determined on deposits were used by specialists IGS NASU as reference on objects with unclear productivity. On these grounds, the boundaries of productive units of investigated deposits (Yuliyivske, Skvortsivske, Nedilne) and contours of perspective areas for hydrocarbon exploration within structures revealed by seismic survey (Lyubotynska, Kuzmychivska, Kadnytska, Bulanivska) were identified.

Both structural and geodynamic parameters and anomalies of hydrocarbons indicate potential productivity of these structures. Anomalies of free hydrocarbons of methane number and unsaturated hydrocarbons (ethylene, propylene) associated with them locate in circumference in regard to those perspective areas. Concentrations of hydrocarbons reach "hurricane values" in many samples, which is an additional confirmation of availability of deposits.

\section{YULIYIVSKA AREA}

Based on the results of thermometric survey of Yuliyivske deposit it is confirmed the spatial variability of temperature field within blocks composing its. According to the distribution of thermal parameters Yuliyivske field is divided into two parts which are the eastern (Dobropilske, Zolochivske raisings) with a relatively increased temperature field and western (Merchykivske, Yuliyivske raisings) where temperature parameters are characterized by lower values. Defined heterogeneity of the temperature field is in accordance with its modern schemes of geo-industrial zoning on the Central and Eastern units.

A characteristic feature of the distribution of radon and thoron anomalies is the spatial coincidence of productive units (according to drilling) and areas with predominantly low and back-end parameters of field. The majority of detected local radon and thoron anomalies spatially tend to NorthYuliyivska zone of violations and smaller local disturbances as is by seismic survey and decryption of satellite imagery defined. Carbon dioxide correlates well with gases emanations distribution. Map of the integral coefficients allocation emphasizes the peculiarities of distribution of radon, thoron and carbon dioxide.

Based on the results of gas survey in subsoil air within Yuliyivske gas deposit hydrocarbons of methane series (from methane to hexane) and unsaturated hydrocarbons (ethylene and propylene) were identified. The majority of local anomalies spatially tend to the eastern part of the field. These gases form a large in size areas of their elevated concentration. According to defined coefficients of pair correlation, all hydrocarbon gases correlate well with each other. Hydrogen correlates well with hydrocarbon gases. In individual points that spatially tend toward the outer boundaries of the deposit, hydrogen concentrations increase to "hurricane" values $\left((1.75-2.74) \times 10^{-3}\right.$ vol. \% $)$.

According to defined indicators, the territory of Yuliyivske deposit stands out as the entire zone with perspective areas, which includes productive Merchykivsky, Yuliyivsky, Dobropilsky and Zolochevsky blocks. Three areas outside the field located along the northern discordant downthrow can be classified as a relatively promising. These areas are characterized by local temperature peaks. They coincide spatially with areas with low values of concentrations of radon, thoron and hydrocarbon gases that are surrounded by their local anomalies, including heavy hydrocarbons [Свдощук, Чебаненко, Клочко, 2001].

\section{SKVORTSIVSKA AREA}

According to the results of thermometric survey, areas of increased temperature parameters correspond to Zahidno-Skvortsivsky and PivdennoSkvortsivsky productive blocks.

In the field of radon Zahidno-Skvortsivsky and Pivdenno-Skvortsivsky blocks stand out as areas of predominantly low and background values. The boundary between these blocks is reflected by the intense radon anomaly. Single local anomalies of radon are recorded also along discordant downthrow which limits Zahidno-Skvortsivsky block from the north. Carbon dioxide correlates well with the distribution of radon and thoron.

Map of the integral coefficients illustrates features of the spatial distribution of radon, thoron and carbon dioxide within Skvortsivske deposit. Its highest parameters spatially tend to the junction between Zahidno-Skvortsivsky and Pivdenno-Skvortsivsky blocks, characterizing it as a zone of current high geodynamic activity. 
The subordination of methane distribution to block structure of Skvortsivske field is observed. The most intense anomalies of methane tend to boundaries of blocks making it up, and to the border with Hukivska area in the east. Distribution of propane concentrations coordinates with the distribution of methane and ethane. Heavier hydrocarbons (isobutane, butane, isopentane, pentane, hexane, ethylene and propylene) are recorded mainly within $\mathrm{Za}$ hidno-Skvortsivsky unit.

According to defined parameters, there are two promising parts within Skvortsivska area in obedience to its block structure. The first one corresponds to Zahidno-Skvortsivsky block whose productivity is proven by the results of drilling, and the second is the most part of Skvortsivsky unit. A significant in size, relatively promising areas within PivdennoSkvortsivsky unit and to the north of PivdennoSkvortsivsky unit were indicated.

\section{LYUBOTYNSKA AREA}

Lyubotynska area is located within the southern mobile zone of the northern edge of Dnieper-Donets basin to the east from Yuliyivske and Skvortsivske deposits and to the southeast from Hukinska structure.

Lyubotynska structure is located between two tectonic zones which stretch to the northwest and belongs to a system of small-amplitude folds. Chain of tectonic disturbances in areas contributes to the development of structural forms with short or nonexistent northern limb and elongated southern limb of fold which are typical for the Northern edge of Dnieper-Donets basin. In planar placement of these structural forms clearly observed zonality caused by stepwise structure of the basement surface, a linear location of local elevations, the presence of extended downthrows and change of capacity of the sedimentary complexes on the background of the Northern edges regional inclination.

According to data of regional forecast, the territory of Lyubotynska area is located in a zone with favorable geological and structural-tectonic conditions. In accordance to data of scientific researches by UkrDGRI, within Lyubotynska structure hydrocarbon deposits in Serpukhovian, Visean sediments and in the crystalline formations of the basement are expected.

Quite clear relationship of the temperature indicators distribution with the geological structure of Lyubotynska area is observed. By temperature in- dicators, area is divided into two parts - the western, which contains Lyubotynska structure and its inclinations and the eastern, presented by shallow monocline. Western part is characterized by high values of temperature, temperature background decreases noticeable within the eastern part. The boundary of these sections of temperature field coincides with the submeridional zone of lineaments, which is defined by the results of decryption of satellite imagery. Tectonic disturbances which were identified by seismic data are less pronounced, on the basis of temperature readings.

Sharp spatial variability of concentrations is typical for radon indicators. Longitudinal structural zoning in a plane placement of radon anomalies is more visible, due to the influence of regional sublatitudinal boundary downthrow. The most active radon anomalies are recorded along its north limb. Here radon concentrations reach extremely high values - to $320 \mathrm{~Bq} / \mathrm{dm}^{3}$. The territory of Lyubotynske vault is characterized by prevalence of low radon concentrations - from 0.001 to $40 \mathrm{~Bq} / \mathrm{dm}^{3}$. The indicators of anomalous radon concentrations spatially tend to transverse tectonic disturbance which stretches in northeast direction and complicates the apical part of Lyubotynska structure. It indicates the contemporary geodynamic activity of this tectonic dislocation. In contrast, the sublatitudinal discordant downthrow is not reflected in radon field, which is typical for shielding violations. The block located to the east from Lyubotynske vault in radon field is distinguished as area with its predominantly higher concentrations.

Distribution of thoron anomalies is similar to radon field. "Cores" of thoron anomalies spatially coincide with the "cores" of radon anomalies, but occupy a slightly larger area.

In most cases, carbon dioxide anomalies spatially coincide with anomalies of gases emanations or tend to them. Planar coherence of emanations field and carbon dioxide field of is more pronounced in the distribution of areas with low concentrations of these gases.

A correlation between gases emanations, carbon dioxide and helium anomalies allows us to consider them as indicators of zones of the deep degassing in the current fault-block geodynamics.

Based on the results of gas survey, anomalies of all methane homologues (from methane to isopentane) are detected within Lyubotynska area. In addition to saturated hydrocarbons, in the sub- 
surface air increased concentrations of unsaturated hydrocarbons (ethylene and propylene) are defined.

General coherence of field figures is typical for all defined hydrocarbon gases. The most common feature is an affinity of sections of fields with low concentrations of gases (background or close to background) to Lyubotynske vault. Abnormal rates of these gases are located planimetric in relation to Lyubotynska structure.

Spatial distribution of ethylene and propylene coincides with the distribution of heavy hydrocarbons of methane series. Based on the results of correlation analysis, all hydrocarbon gases form a unified group with a good positive correlation. It indicates the commonality of hydrocarbon gases migration ways and their connection with the only source of income.

The complex of cartographic constructions forms the basis for the forecast zoning of Lyubotynska area, which include contouring of promising segments for search hydrocarbon deposits. Promising segments correspond to passive in geodynamical terms and low-fluid-permeable blocks, which are surrounded by anomalies of the identified gases. Local anomalies of heavy hydrocarbons indicate, in particular, potential productivity of these segments.

\section{PIVNICHNO-SKVORTSIVSKA AREA}

Researches on the methodology of STAGR were implemented within Kuzmychivska structure and in the adjacent territory from the east in 2009. It was established the following laws of spatial distribution of defined temperature and atmo-geochemical indicators.

Kuzmychivska structure is characterized by reduced value of thermal indicators. It is observed increasing of the temperature field in the northeast and southeast of it.

Kuzmychivska structure corresponds to local maximum of radon field. Some local anomalies are recorded also along the north-eastern and eastern boundaries of Pivnichno-Skvortsivska area.

Distribution of carbon dioxide is in coherence to the distribution of radon and thoron. According to map of integral coefficients distribution, Kuzmychivska structure is allocated as a relatively geodynamic active area. Based on geodynamic indicators, block located to the southeast is distinguished as more favorable for the hydrocarbon traps formation.
Within Pivnichno-Skvortsivska area hydrocarbon gases of methane series (from methane to pentane) and unsaturated hydrocarbons (ethylene and propylene) are discovered. All hydrocarbon gases correlate well with each other. The most intensive hydrocarbon gases field is fixed in the southeast.

By defined indicators, the most promising segment is allocated confidently within PivnichnoSkvortsivska area. It is located on the southern inclination of Kuzmychivske raise.

\section{NEDILNA AREA}

Based on the results of thermometric surveying, Nedilna structure is located in the field with the highest temperature readings.

Radon field is characterized by uneven distribution of anomalous values. Most of the western part of as Nedilna structure is mapped as an area with background values of radon, which confirms the conclusions of its prospects in search for hydrocarbons. Radon anomalies are located planimetric and outside contours in relation to Nedilna structure. Field of thoron and carbon dioxide coincides to distribution of radon anomalies. Nedilna structure is distinguished as potentially productive, according to the distribution of the integral factor.

Based on the results of gas survey, there were identified all derivatives of methane series (from methane to pentane), and ethylene and propylene within the area. All defined hydrocarbon gases correlate well with each other. Their local anomalies are located predominantly outside contours in relation to Nedilna structure.

According to defined indicators, Nedilna structure is characterized as a promising area in search for hydrocarbons. Within its limits and its southeastern extension chain of three spatially adjacent prospective areas is allocated.

\section{KADNYTSKA AREA}

Kadnytska structure is located in structural-tectonic zone of small-amplitude folds to the north from Skvortsivske oil and gas deposit. It is developed above the horst-similar ledge of basement. Results of previous studies, including the drilling of Kadnytska-1 well, are not clear. They include positive conclusions about gas and oil saturation, significant content of helium and good filtration-capacitive properties of rocks, but at the same time, the negative test results of basement rocks. As discussed, the causes can be a choice of the place for well and 
technical preconditions (leaks of the production string) [Багрій, 2013; Чебаненко, Краюшкин, Клочко, 2002]. It should be emphasized that well Kadnytska-1 is located outside promising areas localized by STAGR.

In the temperature field Kadnytsko-Bulanivske raise is characterized by increased parameters. Temperature anomalies spatially tend to local structures Taverivska, Kadnytska and Bulanivska. Tectonic dislocations identified by the seismic data are not clearly allocated in the temperature field.

Kadnytsko-Bulanivske raise corresponds to area with predominance of weakly intensive and background concentrations of radon and thoron. The most intense radon anomalies are located outside contours in relation to raise in general and to local Kadnytska and Bulanivska structures which complicate it.

Local radon and thoron anomalies spatially tend to the nodes of tectonic faults crossing and lineaments. Field of carbon dioxide correlates well with radon and thoron fields.

According to distribution of integral coefficient (for radon, thoron and carbon dioxide) there are three local blocks within Kadnytsko-Bulanivske raise with features of the lowest geodynamic activity and fluid permeability, which allows us to consider them as areas of the most favorable contemporary geodynamic conditions for the formation of potential hydrocarbon traps.

According to the results of gas survey, hydrocarbon gases of methane series (from methane to pentane) within Kadnytska area were identified. Among unsaturated hydrocarbons in subsoil air ethylene and propylene are established. In the distribution of the majority of the of detected hydrocarbons gas anomalies good correlation is observed. Anomalous concentrations of propane, isobutane, butane, isobutane, methane, ethylene and propylene reach an extreme, 'hurricane' values in many locations.

Analysis of obtained by STAGR data allows allocate four segments within Kadnytska area which are promising in search for hydrocarbons traps. There are two relatively promising segments in the southeastern part of the area that tends to shallow Ripkynska local structure.

According to distribution of defined indicators, more complex block structure than previously seemed is typical for Kadnytska area. That is required to consider in further exploration.

\section{RESULTS AND CONCLUSIONS}

The characteristic feature of Yuliyivska, Skvortsivska and Nedilna areas is the presence of helium in subsurface air. In some parts of Yuliyivska area the concentration of helium reach an extreme, "hurricane" values (from $5.42 \times 10^{-3}$ to $63.72 \times 10^{-3}$ vol. \%).ring around the most productive block, in accordance to drilling data. Anomalous concentrations of helium in the subsoil air within the most productive $\mathrm{Za}-$ hidno-Skvortsivsky unit of Skvortsivske deposits were identified (to $26.77 \times 10^{-3} \mathrm{vol}$. \%). The concentration of helium in samples along the western border of Nedilna area reaches an extreme values $\left(14.63 \times 10^{-3}\right.$ vol. \%). Lyubotynska structure is allocated as the area with the prevalence of background concentrations of helium. The largest helium anomalies delineate it from the north, less active and local - from the south.

The conjugacy of hydrocarbon bearing capacity of Northern edge with commercial helium bearing capacity, which is the highest for natural gas and oil of the crystalline basement, indicates that hydrocarbons migrate from the crystalline crust, not from sedimentary strata of Dnieper-Donets graben.

Arguments that allow make this conclusion is also the trace element analysis composition of the oil, which is characterized by depletion and low concentrations of microelements [Чебаненко, Краюшкин, Клочко, 2002].

According to data of thermometric survey the different nature of temperature fields of Skvortsivske and Yuliyivske deposits are detected. Skvortsivske gas deposit is distinguished as area with relatively high background temperatures, while for Yuliyivske oil deposit this background is significantly lower. This difference in geothermal parameters is observed for many oil and gas fields of various oil and gas provinces, including oil and gas regions of Ukraine [Осадчий, Чекалюк, 1967].

These causal relationships between spatiallystratigraphic localization of hydrocarbon deposits in the depths of the earth's crust and the physical and chemical processes of formation which are inherent to the crystalline basement, confirmed the presence of geological, tectonic, aerospace, geochemical criteria necessary and sufficient for justification of its forecasting characteristics and association with deep sources of origin and accumulation.

The general nature of mapped subsurface temperature and atmo-geochemical fields of YuliyivskoSkvortsivskiy landfill indicates sufficiently clear 
features of making up its productive units. The main of them are: 1) affinity of hydrocarbon deposits to the field segments with background values of radon, thoron and carbon dioxide, surrounded by their anomalous concentrations, indicating that there is prevalence of geodynamic stability and weak fluid permeability within them, favorable for the formation and preservation of hydrocarbon deposits; 2) the presence of a weakly intensive halo of methane and ethane above the productive units with location of its anomalies outside contours; 3 ) increasing of thermal indicators value in the subsurface layer above the hydrocarbon deposits; 4) affinity of higher concentrations of radon, thoron and carbon dioxide to tectonic dislocations and external contours of deposits; 5) location of anomalies of heavy hydrocarbons along shielding tectonic dislocations and external contours of deposits.

Laws of formation of hydrocarbon deposits in the crystalline basement are defined by location of this territory in the area of junction of Voronezh anteclise and Dnieper-Donets graben. Influence of tectonic movements on the formation of hydrocarbons, its storage and migration is evident in the formation of decompressed areas of basement rocks, fracture zones of high permeability and other irregularities.

Determination of the structural-tectonic position of area and allocation of geodynamic stable and active segments can provide an outlining of perspective areas and contributes to understanding of peculiarities of oil and gas bearing capacity of crystalline basement.

Summary results of STAGR demonstrate the significant influence of active neotectonic dislocations onto the distribution of temperature and atmogeochemical anomalies. These dislocations are not reflected in seismic structural schemes, but are descramble on satellite images. On the basis of the results of conducted works, multiscale system of lineaments and circular structures is detected. It differs significantly from violations mapped by geophysi- cal methods by location and density of dislocations. According to the results of decryption, YuliyivskoSkvortsivskiy landfill has a complex fragmental structure, caused by a network of crossing lineaments of various directions and arc fragments of circular structures. This defines the necessity of targeted geodynamic analysis and estimation of the conditions for further exploration in separate units. Estimation of promising objects carried out by examining the nature of the distribution of anomalous and background values of individual and integral indicators, considering scrutiny of structural-tectonic characteristics and assessment oil and gas potential of regional structures and local areas.

Integration and interpretation of all data array allows combine thermometric, emanation and gas-geochemical indicators with information about structural and tectonic position into the unified multi-dimensional space which can display the connection between subsurface part of geological environment and detected or predicted deposits.

Improving of the efficiency of search for oil and gas, therefore, should be connected with the study of the nature of various geochemical and geophysical signals from deposits and requires systematic approach to the interpretation of data obtained by different methods of research.

Sufficiently substantiated interpretation of anomalous and background fields of hydrocarbon gases can be implemented in case of a comprehensive analysis of structural, tectonic, thermometric, emanation factors and existing information in regard to oil and gas bearing capacity of the territory. Application of the results of subsurface atmo-geochemical and thermometric surveys is effective only in case of its correct juxtaposition with structural and geological characteristics. The most difficult it is solved in areas with fractional block tectonics, which causes a change in the direction of hydrocarbons migration and determines the distribution of places of deposits formation.

\section{References}

1. Багрій І.Д. Розробка геолого-структурнотермо-атмогеохімічної технології прогнозування пошуків корисних копалин та оцінки геоекологічного стану довкілля. Київ.: Логос, 2013. 511 с.

Bagriy I.D., 2013. Development of geologicalstructural-thermal-atmogeochemical technology of forecasting of search of minerals and assessment of

geoecological environmental state. Kyiv: Logos, 511 p. (in Ukrainian).

2. Свдощук M.I., Чебаненко I.I., Клочко В.П. Теоретичні основи нетрадиційних геологічних методів пошуку вуглеводнів. Київ: НТП "Нафтогаз-прогноз", 2001. 287 с. 
Yevdoshchuk M.I., Chebanenko I.I., Klochko V. P., 2001. Theoretical basis of non-traditional geological methods of petroleum exploration. Kyiv: NTP "Naftogaz-prognoz", 287 p. (in Ukrainian).

3. Kutcherov V., Krayushkin $\boldsymbol{V}$. Deep-seated abiogenic origin of petroleum: From geological assessment to physical theory. Reviews of geophysics. 2010. Vol. 48, iss. 1. P. 12-17.

Kutcherov V., Krayushkin V., 2010. Deep-seated abiogenic origin of petroleum: From geological assessment to physical theory. Reviews of geophysics, vol. 48, iss. 1, p. 12-17 (in English).

4. Landes K., Amoruso J.J., Charlesworth L.J., Heany $\boldsymbol{F}$. Petroleum resources in basement rocks. $A A P G$ Bulletin. 1960. Vol. 44. P. 1682-1691.

Landes K., Amoruso J.J., Charlesworth L.J., Heany $\boldsymbol{F}$. 1960. Petroleum resources in basement rocks. AAPG Bulletin, vol. 44, p. 1682-1691 (in English).

5. Лукин A.E. Прямые поиски нефти и газа: причины неудач и пути повышения эффективности. Геолог України. 2004. № 3. С. 18-43.

Lukin A.E., 2004. Direct search for oil and gas: the causes of failures and ways to increase efficiency. Geolog Ukrainy, № 3, p. 18-43 (in Russian).
6. Осадчий В.Г., Чекалюк Э.Б. Геотермические критерии размещения залежей углеводородов. Условия формирования и закономерности размещеения нефтяных и газовых месторождений на Украине. Киев: Наук. думка, 1967. С. 149-154.

Osadchiy V.G., Chekalyuk E.B., 1967. Geothermal criteria for placement of hydrocarbon deposits. Conditions of the formation and regularities of the location of oil and gas fields in Ukraine. Kiev: Naukova Dumka, p. 149-154 (in Russian).

7. Чебаненко И.И., Краюшкин В.А., Клочко B.П. Нефтегазоперспективные объекты Украины. Нефтегазоносность фундамента осадочных бассейнов. Киев: Наук. думка, 2002. 293 с.

Chebanenko I.I., Krayushkin V.A., Klochko V.P., 2002. Oil and gas promising facilities in Ukraine. Oil and gas bearing capacity of the basement of sedimentary basins. Kiev: Naukova Dumka, 293 p. (in Russian).

Received

April 18, 2017 